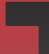
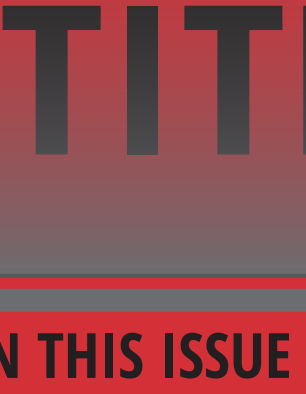

\section{From the Field}

A recent legal win by a student found to be responsible for sexual misconduct

highlights the need to have well-trained

employees who can conduct fair and

impartial proceedings

Page 2

\section{Compliance Corner}

The Office for Civil Rights' 'wink and nod confidentiality' poses some challenges

for institutions.

Pages 4-5

\section{Professional Perspective}

Jessica Ladd-Webert, the director of the University of Colorado, Boulder's Office of Victim Assistance, explains what Title

IX officials can learn from those in victim support roles.

\section{Pages 6-7}

\section{Coordinator's Corner}

RickT. Olshak, the associate dean of

students at Illinois State University and a

certified Title IX administrator, shares five

tips for professional success.

\section{Page 8}

\section{ABOUT US}

The NCHERM Group, LLC., a law and consulting firm offering systems-levels solutions to create safer campuses, and the Association of Title IX Administrators, which provides networking and professional development for Title IX officials, publish Title IX Today, its companion website, www.TitlelX.Today, and subscriber e-newsletter.

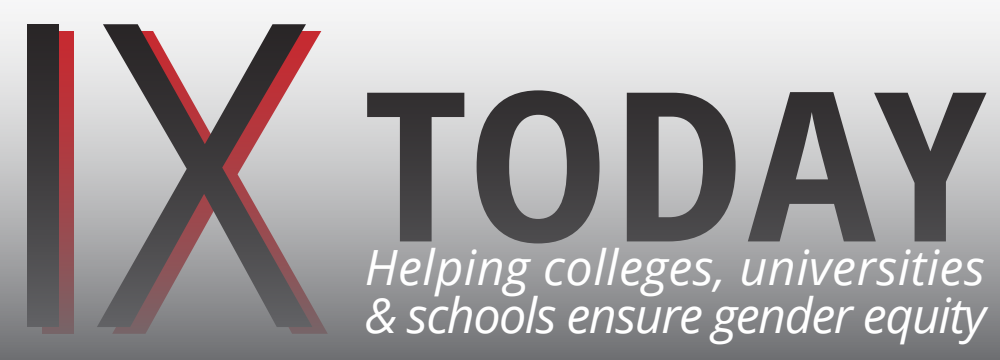

THE LEAD I LIABILITY

\title{
Manage risk of Title IX liability to students disciplined for sexual assault
}

ByErinBuzuvis, J.D.,ContributingEditor

tudents expelled or suspended for sexual assault sometimes bring $\checkmark$ suits challenging the disciplinary decision or the process used to determine the student's responsibility. These lawsuits frequently include Title IX claims. To administrators, it may seem like the risk of liability exists whether or not they discipline students for sexual assault. Yet, the risk of Title IX liability that comes from taking disciplinary measures is one that can be easily managed.

Courts have rec'Courts have recognized two primary theories under which an institution could potentially be liable under Title IX to a student who has been disciplined for sexual assault: erroneous outcome and selective enforcement.'

- Buzuvis ognized two primary theories under which an institution could potentially be liable under Title IX to a student who has been disciplined for sexual assault: erroneous outcome and selective enforcement (see Yusef v. Vassar College, 35 F.3d 709 (2d Cir. 1994)). In an erroneous outcome case, the plaintiff must ultimately convince the court that the institution: 1) reached the wrong conclusion in its disciplinary proceeding; and 2) that the errors in question resulted from gender bias. To survive a motion to dismiss, the plaintiff must allege that particular details could, if proven, establish both of these requirements. tions have prevailed in their motions to dismiss Title IX "erroneous outcome" claims. Often, plaintiffs allege gender bias without the support of specific allegations that would, if proven, establish the truth of that claim. When this deficiency is present, courts are obliged to dismiss the plaintiffs' Title IX claims even if the courts believe it is possible that the plaintiffs could establish that disciplinary decision was in fact erroneous.

Importantly, courts have also rejected the idea that allegations of favoritism for complainants over respondents can serve as evidence of the requisite gender bias, since, as one court put it, the insti-

Continued on p. 3 


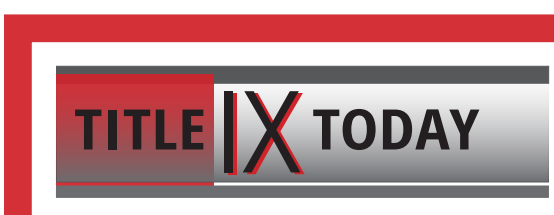

Publisher

Brett A. Sokolow, J.D. Brett@ncherm.org

Editor

Cynthia Gomez, M.A. Cynthia@ncherm.org

\section{Assistant Editor}

Marianne Price, M.S.

Marianne@ncherm.org

Contributing Editors

Leslee Morris, J.D.

Erin Buzuvis, J.D.

Nancy Hogshead-Makar, J.D.

Title IX Today (Print ISSN 23778725 Online ISSN 2377-8733; DOI: $10.17732 /$ TIXT) is published every month by The NCHERM Group, LLC., 1109 Lancaster Ave., Berwyn, PA 19312.

\section{ANNUAL SUBSCRIPTION:}

\$299: Includes one issue per month, sent via postal mail and emailed in PDF format, along with additional premium content, each month to subscribers.

\section{TO ORDER:}

Phone: (610) 993-0229

Fax: (610) 993-0228

Email: Amanda@ncherm.org

URL: www.ncherm.org/store

Postmaster: Send address changes to Title IX Today, The NCHERM Group, LLC., 1109 Lancaster Ave., Berwyn, PA 19312.

Copyright (c) 2015 The NCHERM Group, LLC. All rights reserved. Except as permitted by the 1976 United States Copyright Act, no part of this publication may be reproduced or stored in a retrieval system in any form or by any means without prior written permission.

Reprint requests may be sent directly toCynthia@ncherm.org. Reprint authorization may also be acquired through payment of a per-copy fee to the Copyright Clearance Center, located at 222 Rosewood Dr., Danvers, MA 01923. Phone: (978) 750-8400; Fax (978) 6468600; Web: www.copyright.com.

Title IX Today is intended to provide authoritative guidance on Title IX matters, but its contents should not be taken as legal advice. If such advice is required, please seek legal counsel.

\section{Ensure due process for all parties, or risk legal losses}

\section{ByCynthia Gomez, Editor}

1 recent decision in the case of Doe v. Regents of the University of California, San Diego, highlights the importance of ensuring that hearing panels are well trained in how to conduct fair and balanced proceedings.

San Diego County Superior Court Judge Joel M. Pressman ordered the institution to drop its finding and sanctions against a student accused and found responsible of sexual misconduct by the university's hearing panel.

The student, identified in court records as John Doe, met the reporting party, identified as Jane Roe, at a party in 2014. They began a sexual relationship. Several months later, Roe alleged three instances of sexual misconduct on Doe's part. The institution's complaint resolution officer found Doe responsible for one of those claims, involving non-consensual sexual intercourse. A hearing panel affirmed the finding, recommending that Doe be suspended for one quarter and undergo sexual harassment training and counseling assessment. Doe sent a letter of appeal to the dean of student affairs, who responded by increasing the suspension period to one year.

The court's findings regarding the adjudication process hold important implications for institutions everywhere. It found that Doe did not get a fair shake. The judge pointed out that of the 32 questions Doe submitted to the panel for Roe, the hearing chair asked Roe just nine. Further, he opined that the panel should not have accepted the complaint resolution officer's findings without allowing Doe to confront and cross-examine the reporting party. In addition, the court faulted the fact that the institution failed to provide Doe with access to the 14 statements made by Roe and witnesses during interviews. Also, the panel inappropriately took Doe's choice to exercise his Fifth Amendment rights by refusing to answer some questions as evidence of responsibility, the court found. And in increasing the sanctions against Doe after he appealed, the institution "abused its discretion." Doe was not given a reason for the sanction change. The judge noted that "it appears the increased sanctions are punitive towards [Doe] for appealing the decision of the panel," he said.

The key takeaway here is clear. Due process must be provided to all parties in Title IX-related cases, and failure to do so could result in liability. $\diamond$

\section{EDITORIAL ADVISORY BOARD}

Brett A. Sokolow, J.D.

President, The NCHERM Group, LLC.

Executive Director, Association of Title IX Administrators

Nancy Hogshead-Makar, J.D. Chief Executive Officer, Champion Women

Daniel C. Swinton, J.D., Ed.D. Managing Partner, The NCHERM Group, LLC.

Michele Paludi, Ph.D. Participating Full Professor, Union Graduate College
Erin Buzuvis, J.D.

Professor, Western New England University School of Law

Director, Center for Gender \& Sexuality Studies

W. Scott Lewis, J.D. Partner, The NCHERM Group, LLC.

Saundra K. Schuster, J.D. Partner, The NCHERM Group, LLC.

Brian Van Brunt, Ed.D. Senior Exec. VP for Professional Program Development, The NCHERM Group, LLC. 
Continued from p. 1

tution "is not responsible for the gender makeup of those who are accused by other students of sexual misconduct" (see King v. DePauw Univ., 2014 WL 4197507 (S.D. Ind. Aug. 22, 2014)). Therefore, as long as an institution has gender-neutral policies that would treat accused students the same regardless of their sex/gender, the fact that most or even all of those students tend to be male will not serve as evidence of gender bias.

In one recent case, however, a court denied a motion to dismiss a disciplined student's erroneous outcome claim (see Wells v. Xavier Univ., 7 F. Supp. 3d 746 (S.D. Ohio 2014)). There, the plaintiff argued that Xavier University erroneously determined that he had sexually assaulted a female student, a claim he supported with allegations of specific procedural flaws that could have affected the outcome. He satisfied the court's additional requirement for specific allegations of gender bias by claiming that the university had been under investigation by the Department of Education for not adequately responding to earlier female students' reports of sexual assault, which he claimed motivated university officials to make an example of him.

The court agreed that if the plaintiff could prove this was true, it would be a plausible basis for the jury to find that Xavier violated Title IX. Rather than continue to litigate the case, the parties agreed to a settlement of undisclosed terms. As this case shows, sometimes a plaintiff's allegation of bias will be sufficient to deprive a university the convenience of a quick dismissal. But because the plaintiff must allege both bias and error, even an institution that is vulnerable to allegations of bias, as Xavier was, can improve its chances of winning a motion to dismiss by ensuring that its investigation and disciplinary process is beyond reproach. Procedural integrity also insulates against other claims that are likely to be raised by disciplined students, such as negligence and breach of contract, and greatly reduces the risk to public universities of liability under the constitution's due process clause.

Unlike erroneous outcome claims, plaintiffs in selective enforcement claims do not need to argue that they were disciplined in error, just that they were singled out for punishment because of sex. Essentially, the plaintiff, if he is male, must show that the institution does not discipline women, or disciplines them less severely, for the same conduct. For example, a male plaintiff was allowed to pursue a Title IX selective enforcement claim based on the allegation that his law school considered a female complainant's charges against him but disregarded his complaint of assault against another student (see Vaughn v. Vermont Law School, 2011 WL 3421521 (D. Vt.2011)). Still, administrators can effectively reduce the risk of having to litigate selective enforcement claims by ensuring that both on paper and in practice, the institutional response to reports of sexual assault is gender neutral. Policies should not assign genders to the role of accuser and accused, nor should they reflect gender stereotypes as to who is in which category. Administrators should take reports of sexual assault committed by women as well as men with equal seriousness.

With these considerations in mind, it is possible for careful administrators to fulfill their obligations under Title IX to respond to sexual assault while avoiding both liability and litigation over Title IX claims filed on behalf of disciplined students. By ensuring that policies and practices are gender-neutral, and that published procedures are faithfully applied in all cases, institutions can more effectively manage the risk of Title IX liability, as well as liability under other claims, that may arise in the course of disciplining students for sexual harassment and assault. $\diamond$

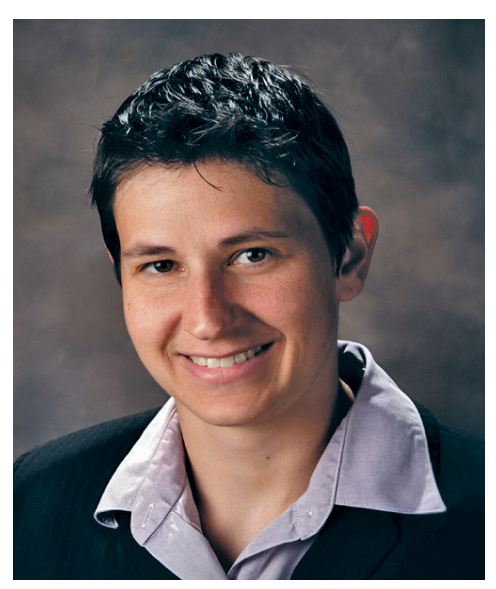

ERIN BUZUVIS, J.D.

Erin Buzuvis is a professor at the Western New England School of Law and serves as director of the Center for Gender \& Sexuality Studies.

\section{KEY TAKEAWAYS}

" Fear of lawsuits by responding parties disciplined for sexual misconduct is not unreasonable, given the recent rise in such cases. But that should not stop institutions from disciplining responsible parties.

" Though it is rare for courts to rule against colleges and universities in discipline cases, institutions could potentially be liable under Title IX to a student disciplined for sexual assault for erroneous outcome or selective enforcement.

" The risk of liability from disciplined students can be lessened by ensuring that published policies and procedures are gender-neutral, and that they are applied consistently. $\diamond$ 


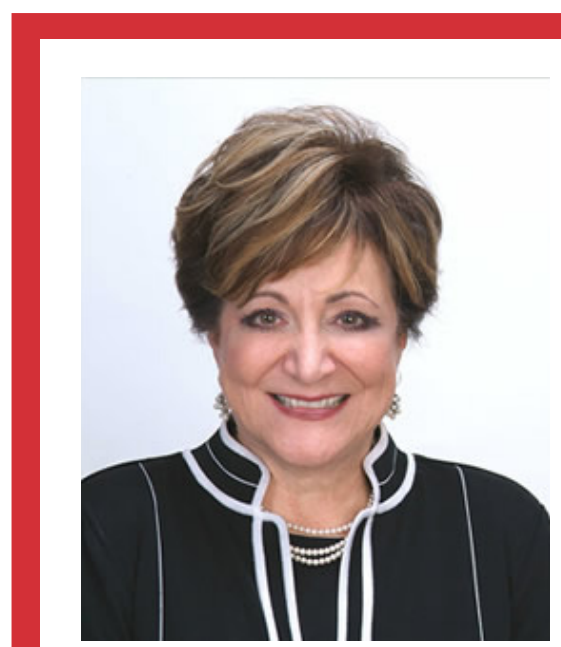

SAUNDRA K. SCHUSTER

Saundra K. Schuster serves as a partner at The NCHERM Group, LLC. For more information, she may be reached at Saundra@ncherm.org.

\section{KEY TAKEAWAYS}

» Neither Title IX nor its regulations create an obligation to provide confidentiality, yet OCR acts as if that obligation exists.

"When OCR talks about "confidentiality," it's really referring to "privacy." The former refers to privilege bestowed by law or licensure, while the latter refers to needless intrusion into personal affairs and/ or information.

» Help employees understand what information they can keep to themselves, and what information they have a duty to share.

» Encourage employees to explain their reporting obligations before students disclose information to them about Title IX-related incidents, with a focus on using language that accurately conveys what they can keep to themselves. $\diamond$

\section{'Wink-and-nod confidentiality' poses challenge for institutions}

BySaundra K. Schuster, J.D.

7 he word "confidentiality" carries an important message. It 1 means a "secret to be kept by another," or "pinky-swear." It doesn't mean, "I will keep your story confidential - unless the 'law' doesn't allow it, or to the extent of the law." What does that really mean in human speak? When you assure another person that you will keep information confidential, that person doesn't think your confidentiality comes with conditions.

And yet, the U.S. Department of Education's Office of Civil Rights uses that word loosely when it comes to Title IX, suggesting that we can maintain the confidentiality of our processes, or that we somehow have the administrative power to create confidential reporting sources within our institutions.

Neither Title IX nor its regulations say anything about institutional obligation to maintain confidentiality. Yet, OCR acts as if the law creates such an obligation, and the word "confidentiality" is used frequently by the agency in reference to Title IX. That makes sense, given the extremely sensitive nature of many Title IX-related complaints. Don't get me wrong, I like the concept of assuring another person that I will respect that person's request for privacy. But privacy isn't absolute, and it is not the same thing as confidentiality.

Schools, colleges, and universities should make every effort to create and support safe reporting pathways (as recommended by OCR in its 2014 Frequently Asked Questions).
These pathways are for private reporting sources - individuals who report information while maintaining the privacy of the reporting party's identity, thus enabling those sources to provide information and support. But this is not the same as "privilege," the confidentiality extended to therapists, ministers, and in some states, advocates designated by state law.

Those laws confer on those trained individuals the right to "keep information in the vault," except in extreme circumstances such as when there is an imminent threat of harm to self or others. They are individuals we can trust, and who will keep our secrets and our personal stories under all circumstances, not only conditionally.

In the context of Title IX, "confidentiality" doesn't really mean "confidentiality." While OCR uses the term in referring to institutional obligations under Title IX, what it's really referring to is privacy. The two words are not interchangeable.

"Confidentiality" is a term with specific and stringent legal connotations. It is established by law or licensure requirements. Information provided in confidence cannot be shared without the divulging party's express consent, except, as noted earlier, when a threat of harm is imminent. "Privacy," on the other hand, refers only to freedom from needless intrusion into personal affairs and/or information. While OCR may often talk about the need to ensure confidentiality in Title IX matters, it cannot require true confidentiality from 
educational institutions under this law for two key reasons.

First, non-privileged faculty and staff members who are not designated as "responsible employees" under school policy and receive notice of a Title IX-related incident may still be required to report information to Title IX officials under certain situations. For example, resident assistants may be told that they can serve as "confidential" reporting sources, but may still be required to report information in the aggregate to the Title IX coordinator.

Even if, as the Association of Title IX Administrators recommends, all employees are designated as mandatory reporters by a school, an RA might be considered as such only while on the clock and/or only in relation to the students for whom $\mathrm{s} /$ he has professional responsibility. Also, sexual misconduct involving minors is likely to fall under a state's definition of child abuse, and thus be subject to mandatory reporting by all campus employees.

Second, and perhaps more importantly, institutions have an obligation to investigate and address Title IX-related incidents that may pose an imminent and continuing threat of harm to the reporting party and/or other members of the campus community, regardless of whether the reporting party wants any action taken or requests confidentiality. Why?

Educational institutions must balance such confidentiality requests with the obligation to ensure a safe, and nondiscriminatory environment for all members of their campus communities. If there is a history of complaints against an accused individual, further harm has been threatened, a pattern of predation seems present, or a weapon was involved in an incident, the Title IX coordinator may decide that, despite a student's wish for confidentiality, a formal report must be filed and investigation initiated. In such situations, a school may take every step that is reasonably possible to ensure privacy, but not confidentiality. That means that information about a reporting party and incident will be shared with only those employees who have a legitimate need to know, and information will be kept in a secure manner.

OCR has done us a disservice by creating this sort of "wink-and-nod" confidentiality, where some college and university employees can tell students that they can maintain information shared in confidence, when in some cases, they have a duty to share what they learn with the Title IX coordinator. One big downside of this conditional "confidentiality" is that students who report incidents under the impression that they were assured confidentiality may think twice before making any future reports upon finding that previous reports were not truly confidential. Whether or not disclosure was necessary, reporting parties are likely to feel betrayed, and that can have a chilling effect.

So what's a college or university to do? Faculty, staff members, and administrators should be explicit with everyone regarding their obligations under Title IX. For instance, before a student has a chance to share any information about a Title IX-related incident, the employee on the other end of the report should explain exactly how far his/ her ability to provide "confidentiality" extends.

If legal privilege is not present, the employee should tell the student about truly confidential sources on campus, or out in the surrounding community. That allows students to make educated choices about what to disclose and to whom. A good way to avoid unintentionally betraying students is to avoid the word "confidentiality" altogether, using instead "privacy" to refer to conditional "confidentiality" as described by OCR, or "privilege" to describe legally- or professionally (licensure)- bestowed confidentiality.

So what happens if a faculty member who has no legal privilege explains that "confidentiality" under Title IX only goes so far, and a student still chooses to share details of a recent and violent rape? Reiterating the employee's legal duty to share that information with the Title IX coordinator is always a good idea. The key is to tell students prior to making disclosures, even if students' lack of consent for disclosure is clear.

Despite OCR's talk about institutional obligation to maintain confidentiality, it's best to err on the side of caution; that is, encourage college employees to share information with your Title IX office if they feel that sharing it is necessary to ensure the safety of individuals or the greater campus community.

It comes down to what lawsuit you would prefer to face: the one claiming that your institution knew about a situation and failed to take action, or the one claiming that your college moved to protect a student or the campus community from what it perceived to be a real threat of harm. Explaining that while you may not be able to maintain confidentiality but will do everything possible to keep information about involved students and an incident quiet can go a long way toward mitigating legal risk. $\diamond$ 


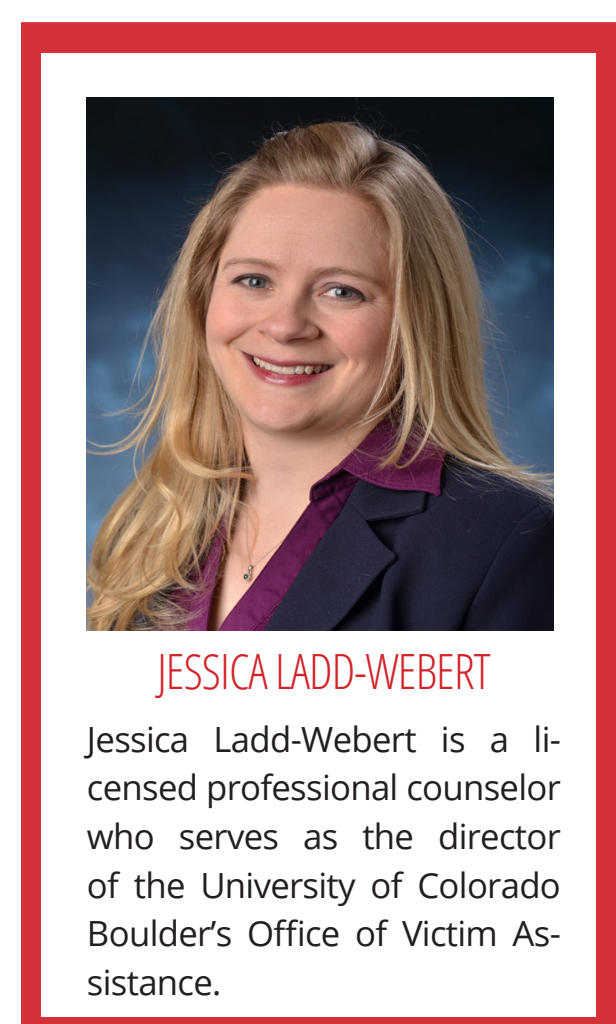

\section{KEY TAKEAWAYS}

" Even with the recent media coverage of Title IX and related incidents, the average college student needs much more information on the law.

„ False reports are incredibly rare, partly because it takes a lot of time, energy, and emotion to go through the reporting process.

" Don't just look for direct threats. Look for patterns and history, especially with stalking and intimate partner abuse.

" Give students support options, including confidential ones, if they're not already working with a victim advocate, as this can help keep them more engaged in the process. $\diamond$

PROFESSIONAL PERSPECTIVE I SEXUAL MISCONDUCT

\section{Title IX administrators can learn from victim advocates}

ByLeslee Morris, J.D., Contributing Editor

Tessica Ladd-Webert, a licensed professional counselor who serves as the director of the University of Colorado, Boulder's Office of Victim Assistance, represented mental health services as a negotiator for the federal rulemaking sessions on the reauthorization of VAWA in 2014, and participated in roundtable discussions on campus sexual assault. She was awarded the 2015 Colorado Visionary Voice Award from the National Sexual Violence Resource Center. As legislators now consider the proposed Survivor Outreach and Support Campus Act, which would require institutions to designate an independent advocate for campus sexual assault prevention and response, LaddWebert shares what Title IX administrators can learn from victim advocates.

\section{Could you share a little about} your background?

I have been at $\mathrm{CU}$ for eight years $A$ and have been doing advocacy work for more than 12 years. I got my start as an advocate for a sheriff's office, then worked as an advocate counselor for a rape crisis center. My master's degree is in community counseling.

\section{What exactly is a victim ad- vocate?}

A This is someone who helps emA power survivors of crime, violence, and/or trauma. Advocates help make sure individuals know all their rights and options, so they can make informed decisions. Advocates also help victims access resources and feel supported in doing what feels best for them. Why would someone not report sexual misconduct to a school or police?

A Many people choose to not share their experience with anyone at all. They may be worried how others will react. Some do not understand what happened; they may not yet have words for it. Others may feel confusion, shame, or denial. If victims initially disclose to a friend, partner, or parent and receive a negative response, they are less likely to report to an authority figure. Some just do not want to think about it, and reporting means talking about it and continuing to remember it. When someone experiences a trauma, there is some loss of control, and there may be fear reporting will exacerbate that. Others are afraid the police or the school will not believe them. For those reasons, some people will confide in a counselor or victim advocate, but not report to the school or police.

What do you know that might
surprise Title IX coordinators and/or investigators?

A Advocates are not working A against the school or the criminal justice process. Advocates really want victims to know all their options, but then we support what they feel is best for them, as they are the ones who had the experience. Additionally, the vast majority of students really do not know what Title IX is and have no idea what their rights or options are under Title IX. The average student still needs much more information on this, and in a way that is easily understood.

The Office for Civil Rights specifies that the school's Title IX response needs to be traumainformed. What does that mean?

A It refers to promoting safety and $A$ building rapport and trust with survivors; giving them options with a goal of empowerment; understanding the impact of trauma on cognitive, physical, psychological, emotional, and 
neurobiological levels; understanding how trauma can impact the academic and social aspects of their lives; and knowing positive ways to respond to and support a survivor. Cultural awareness/competence is also important.

Investigators might struggle with needing to preserve impartiality while asking about sensitive issues. What do you suggest?

You can be impartial and still be A empathetic and trauma-informed. Listen and build rapport. Get to know survivors, what they are studying, where are they from, etc. Don't just jump into interview mode. Explain who you are and the process. The advocate may have already done this, but students will want to hear from you directly. Let them share their experience and then follow up with questions. Explain the reasons you're asking the questions. Summarize what you hear, as this shows you are listening and ensures you understand what is being shared. Normalize and validate the feelings they are expressing. Avoid questions that start with "Why." It's also helpful to connect them to confidential support services before, during, and after your interview.

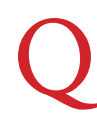

There's some concern about victims reporting things that they believe to be true but that didn't actually occur. There's also a perception that students sometimes report victimization to cover up infidelity, to excuse bad grades, or because they feel used after a consensual encounter. Thoughts?

A This is very rare. Reporting takes A up a lot of time, energy, and emotion. Coming forward puts victims under scrutiny and makes them vulnerable. Most people wouldn't put themselves through that if something didn't occur. I'm not seeing victims confusing past victimization with more recent sexual encounters, but of course, my job is to believe and support victims.
Many campuses are struggling with cross complaints in relationship violence cases. What should we know?

Look for who the primary aggresI sor is and whether there is any violence happening by the target/survivor as a way to protect from escalation in the abuse. It is important to look beyond one incident, and at the whole relationship, since partner violence does not usually happen only in a snapshot.

@ What should we know about stalking on college campuses? While some stalking incidents A may involve threats, many involve other forms of repeated, unwanted attention, such as texts, emails, voicemails, and/or social media posts, showing up outside of a class or dorm room, and leaving unwanted gifts. Victims may feel fear and respond by changing everyday patterns or routines, such as not going to class or avoiding certain areas or friends. It's important to not only focus on threats, but to also look for repeated behaviors that change someone's everyday routine.

What do you see as the areas colleges need to most improve upon to provide an effective response to Title IX incidents?

$\Delta$ Continue to provide survivors I with access to confidential support services. This will lead to a more supported and informed campus community, where survivors are more likely to stay engaged in the process and the impact of trauma may be mitigated. One way to start to make a change in the culture is to be $\mathrm{OK}$ with seeing an increase in reporting, as this may mean that students feel supported and believe the campus will help address situations. $\diamond$

\section{About the Author}

Leslee Morris serves as an associate at The NCHERM Group. She was previously the Title IX compliance and grievances coordinator for $\mathrm{Na}$ tional University. You may contact her atLeslee@ncherm.org.

\section{SUBSCRIBE TODAY}

$\square$ Yes, I'd like a one-year subscription to Title IX Today, which includes one eight-page issue per month, in print and PDF, along with access to additional premium content delivered via email, all for just $\$ 299$.

Simply fill out this subscription coupon with your information and payment option, and mail it to us at: The NCHERM Group, LLC., 1109 Lancaster Ave., Berwyn, PA 19312. Make checks payable to The NCHERM Group, LLC.
Name:

Title:

Mailing Address:

Email:

Phone:
Check is enclosed.

$\square$ Amex $\square$ MC $\square$ Visa

Card \#:

Expiration:

Security Code:

Cardholder Name:

Signature:

For payment questions, please email Marianne@ncherm.org. 


\section{IIIILEIXIODAY}

\section{Set yourself up for professional success: 5 tips}

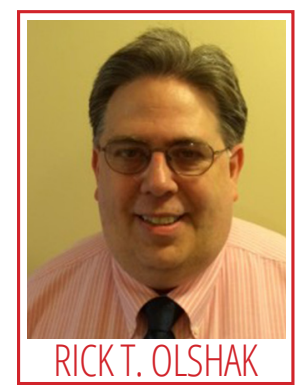

$\mathrm{R}$ ick T. Olshak, the associate dean of students at Illinois State University, is a certified Title IX administrator who serves as an advisory board member for ATIXA, the Association of Title IX Administrators. He's also an affiliated consultant with The NCHERM Group, LLC. Having investigated and adjudicated Title IX cases for 25 years, he shares some tips that have aided him. 1 Build relationships. While Title 1 IX officers are by nature content experts, our success hinges on our ability to forge and maintain relationships across our academic communities. We must engage both stakeholders and critics alike in mutual learning.

2 Network. While building relationships on campus is critical, Title IX officers often understand other Title IX officers best. Take advantage of the ATIXA listserv and conference to develop relationships. Moreover, pick up the phone and call your colleagues around the country when you need advice.

2 Keep learning. Title IX is not a 3 settled area of educational law. Government legislation and regulation continue to add to the complexity of our work. It's critical that we stay as current as possible. Keep a folder with every article you need to read, and attend training and development programs as your schedule and budget allow.

1 Think local. Manyjob listings seek4 ing Title IX officers state a desire to create a "national model" for addressing Title IX issues. So how do programs become considered best practice? Simply put, by working with your community to create programs and services that not only achieve compliance, but also do right by all parties. By staying focused on these priorities, you will achieve success that will not go unnoticed.

5 Keep yourself centered. Title IX 5 work is challenging; it is critical that we maintain perspective. Consider advising a student organization or creating other opportunities to see the positive aspects of your campus community. Personally, maintain a focus on health and family, and take time to enjoy life away from the office. Taking our work home, either literally or figuratively, sets us on a path for professional burnout. $\diamond$ 